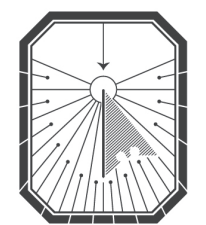

KYIV-MOHYLA

LAW \& POLITICS JOURNAL

KYIV-MOHYLA SCHOLARLY PEER-REVIEWED JOURNALS

Participatory Governance in Ukraine: A Case Study of Anti-corruption Policy in the Period 2014-2018

Author(s): Denitsa Marchevska

Source: Kyiv-Mohyla Law and Politics Journal 6 (2020): 107-137

Published by: National University of Kyiv-Mohyla Academy

http://kmlpj.ukma.edu.ua/ 


\title{
Participatory Governance in Ukraine: A Case Study of Anti-corruption Policy in the Period 2014-2018
}

\author{
Denitsa Marchevska \\ Doctoral Researcher \\ Leiden University, The Netherlands
}

\begin{abstract}
The 2013-2014 Euromaidan Revolution, which culminated in the fall of the authoritarian and notoriously corrupt regime of President Victor Yanukovych has become a symbol of the triumph of civic activism in Ukraine. Although those events have attracted significant scholarly attention, the question whether the Ukrainian civil society's capacity for protest mobilization has successfully been channeled into sustained, formalized and productive forms of civic participation in the process of public policy making has remained largely unaddressed. Therefore, this paper sets out to examine whether civil society organizations (CSOs) have become more integrated into the Ukrainian public policy making process since the Euromaidan and whether the Revolution has led to a meaningful shift towards a more open and inclusive style of governance. Drawing on legal texts, external reports and semi-structured interviews with Kyiv-based anticorruption activists, the study finds both a clear trend towards increased openness of the policy making process to CSO input in the immediate aftermath of the Revolution as well as the insufficient consolidation and institutionalization of such participatory mechanisms, which ultimately makes them vulnerable to the preferences of individual players and to broader changes in political attitudes.
\end{abstract}

Key Words: civil society, participatory governance, anti-corruption, public policy, Ukraine

\section{(7)}

\section{Introduction}

The repressive and totalitarian nature of the Soviet political system is widely acknowledged to have contributed to the chronic weakness of civil society in Ukraine and other post-Soviet states. ${ }^{1}$ This weakness has impeded the process of establishing productive cooperation between the state and civil society throughout much of Ukraine's modern history. As a result, civil society organizations (CSOs) and the wider population of Ukraine have traditionally been mostly detached from the political

1 Howard, M. The Weakness of Civil Society in Post-Communist Europe. Cambridge, U.K. ; New York, NY: Cambridge University Press, 2003. 
process and have had a limited influence on political outcomes, which has remained dominated by traditional state structures and political elites. ${ }^{2}$

In contrast to this legacy, the 2013-2014 Euromaidan Revolution, which culminated in the fall of the authoritarian and notoriously corrupt regime of President Victor Yanukovych, however, has become a symbol of the triumph of civic activism over state dominance. The Revolution brought Ukrainian civil society to the forefront of political life and led to an explosion in civic activism, unprecedented in the country's post-Soviet history. The post-Euromaidan period has witnessed an increased popular demand for democratization, widening of the public space and a public commitment to the establishment of a more participatory policy making process, in which citizens have more opportunities for engagement. ${ }^{3}$ The process has been driven by significant pressure as well as practical assistance by donors and international actors such as the European Union and the Council of Europe, who have incorporated provisions demanding the establishment of more inclusive policy practices in a number of action plans and developmental strategies for Ukraine. ${ }^{4}$

Although those events have attracted significant scholarly and journalistic attention and literature studying the phenomenon of Ukrainian civil society and activism have been prolific, ${ }^{5}$ the question whether the Ukrainian civil society's capacity for protest mobilization has successfully been channeled into sustained, formalized and productive forms of civic participation in the process of public policy making has remained largely unaddressed. There has been relatively limited systematic academic inquiry into the degree to which the Revolution facilitated a more participatory policy process as well as into the ability of civil society organizations (CSOs) to establish themselves as legitimate partners in the policy making process in post-Euromaidan Ukraine.

This paper seeks to address this deficit of academic work examining the cooperation between Ukrainian authorities and CSOs on policy matters as well as the

2 Vakulenko, V., N. Grynchuk, and H. Borshch. "Report on Public Administration Reform in Ukraine." Network of Institutes and Schools of Public Administration in Central and Eastern Europe (NISPAcee), 2014, 5 .

3 Burlyuk, O., N. Shapovalova and K. Zarembo. "Introduction to the Special Issue Civil Society in Ukraine: Building on Euromaidan Legacy." Kyiv-Mohyla Law and Politics Journal 3 (2017): 1-22.

4 For example: Council of Europe. "Strategic Priorities for Promoting Civil Participation in Decision making in Ukraine." Council of Europe, 2014.; European External Action Service. "Ukraine -EU Country Roadmap for Engagement with Civil Society 2014-2017." European External Action Service, 2014.

See for example: Sereda, V. “I Am a Man and an Active Citizen... I Did Not Betray My State!" Revue Detudes Comparatives Est-Ouest $\mathrm{N}^{\circ}$ 2, no. 2 (September 24, 2018): 93-130; Falsini, S. and S. Worschech. The Euromaidan's Effect on Civil Society: Why and How Ukrainian Social Capital Increased after the Revolution of Dignity. Soviet and Post-Soviet Politics and Society, Vol. 182. Stuttgart: ibidem-Verlag, 2018; Burlyuk et al., Introduction to the Special Issue; Shyrokykh, K. “The Euromaidan's Effect on Civil Society. Why and How Ukrainian Social Capital Increased After the Revolution of Dignity." Europe-Asia Studies 72, no. 2 (February 7, 2020): 333-34. 
topic of civic participation in policy making after the Revolution more generally. As such, it aims to contribute to the wave of scholarship on Ukrainian and post-communist civil society and to the literature on participatory governance and civil society advocacy in a wider sense.

The article sets out to examine whether civil society organizations have become more integrated into the Ukrainian public policy making process since the Euromaidan and whether the Revolution has led to a meaningful shift towards a more open and inclusive style of governance. The article focuses specifically on the field of anticorruption policy making and limits itself to the period immediately following the Euromaidan, namely 2014-2018, which coincides with the term of the government of President Petro Poroshenko. The paper looks at the input and role of professional civil society organizations with explicit commitment to policy advocacy, which operate on the national level. Given the expertise, resources and proactive engagement of such actors they are expected to be willing participants in participatory mechanisms and the most obvious partners to the state in case of increased openness of the political system to external participation.

The research question is addressed through the use of a dedicated theoretical framework of state-CSO relations which pays particular attention to the degree of transparency of the policy making process, the legal framework for engagement with civil society actors in the policy process as well as the degree of institutionalization of civic participation. The study highlights both the presence of a clear trend towards openness of the policy making process to CSO input in the immediate aftermath of the Revolution as well as the insufficient consolidation and institutionalization of such participatory mechanisms, which ultimately makes them vulnerable to the preferences of individual players and to broader changes in political attitudes. Overall, findings raise questions about the extent to which initial positive developments observed in the immediate aftermath of the Revolution can be treated unambiguously as a sign of a large-scale and sustainable shift towards participatory governance.

For the purposes of this study, 14 semi-structured interviews with representatives from Kyiv-based CSOs operating on the national level and engaged in anti-corruption activity and policy advocacy were carried out in May 2018. In the course of the interviews, activists were asked to elaborate on their own anti-corruption activities and their advocacy work. In addition, they were asked a number of open-ended questions inviting them to reflect on their perceptions of state-CSO cooperation, the degree of institutional openness to dialogue as well as on their own experience of cooperating with representatives of the state.

This paper consists of three main parts. The first section offers an overview of the theoretical framework which will be utilized for the analysis. The second and main section of this article represent the empirical analysis as per the theoretical framework. The study concludes with a discussion of the main findings and trends as well as avenues for further research. 


\section{Types of State-CSO Relations - a Framework for Analysis}

In order to examine the extent to which civil society has successfully established itself as a meaningful participant in the policy making process, this paper puts forward an analytical framework incorporating three key aspects of state-CSO interaction and cooperation. Those are the degree of clarity and predictability of the decision-making process, the nature of the existing legal framework for including CSOs in decision making and the extent to which dialogue has been formalized and institutionalized in practice. Those are then used to construct a model consisting of six ideal-type categories describing state-CSO relations according to the degree of state openness to policy dialogue and the general patterns of interaction underlining the policy process.

This framework has been informed by the classic Coston model of government-NGO relations, ${ }^{6}$ by the levels of participation spectrum used by the European External Action Service in its guidelines for "Code of Good Practice for Civil Participation" 7 as well as, to a lesser extent, by the "continuum of participation" developed by Karl. ${ }^{8}$

While the main assumptions and the structure of these conceptualizations have been used as a departure point, the framework has been developed further in order to fit the needs of the present study as well as to incorporate indicators which are particularly relevant to the Ukrainian context and the topic of anti-corruption. For example, the current framework will preserve the attention to the mode and specificity of existing forms of dialogue ${ }^{9}$ as well as the consideration of particular dynamics of power asymmetry between government and non-state actors within them. ${ }^{10}$ However, it will seek to address limitations such as the fact that those models fail to take into account advocacy-oriented activities and wider systemic issues, which might facilitate or obstruct civil society's input. At the same time, it has sought to mimic Coston's macro-level approach, which allows for an account of the existing systemic conditions and environment as opposed to the more limited scale of other models which focus on a narrower set of indicators.

In addition, the present model incorporates indicators considering the transparency of the decision-making process as well as the de facto respect for existing

6 Coston, J. “A Model and Typology of Government-NGO Relationships.” Nonprofit and Voluntary Sector Quarterly 27 (1998): 358-82.

European External Action Service. "Code of Good Practice for Civil Participation in the Decision making Process. Adopted by the Conference of INGOs at Its Meeting on ${ }^{\text {st }}$ October 2009." EEAS, 2009, accessed December 12, 2020, https://www.eesc.europa.eu/resources/docs/ code-of-good-pratice-for-civil-participation-in-the-decision making-process-en.pdf.

8 Karl, M. "Participatory Policy Reform from a Sustainable Livelihoods Perspective: Review of Concepts and Practical Experiences." LSP Working Paper 3, Participation, Policy and Local Governance Sub-Programme. FAO, Rome, 2002, accessed April 13, 2020, http://www.fao.org/ docrep/oo6/ad688e/ad688eo3.htm.

9 Karl, Participatory Policy Reform; EEAS, Code of Good Practice. 
legal provisions for engagement as signs of genuine commitment. These adjustments have been made due to the fact that although the risk of "mimicking" has been widely acknowledged, especially in less democratic and corrupt environments such as the one found in Ukraine," this issue has largely been overlooked by existing conceptualizations. Given the focus of this paper on the post-Soviet space and the anti-corruption field in particular these modifications are highly relevant.

Although the model will provide the basis of the empirical analysis, it is recognized that it represents an ideal-type conceptualization and real-world political systems and state-society relations are unlikely to fit any of the identified categories perfectly. The relatively fluid nature of the categories themselves also naturally means that any evaluation represents an inherently interpretative exercise and cannot be considered a precise and clear-cut process. It should also be acknowledged that political regimes and governments are not always monolithic entities and thus it is possible that the level of openness of various agencies and institutions might vary considerably. Therefore, while a loose association could exist between the typologies presented and certain regime types, the performance of regimes or particular bodies according to the framework alone cannot be used as a reliable indicator of regime type.

\section{Clarity and transparency of the decision-making process}

There is a wide-spread consensus regarding the importance of institutional transparency as a facilitating factor for effective CSO advocacy and public scrutiny of political activity. ${ }^{12}$ Although not sufficient for ensuing effective state-CSO policy dialogue on their own, ${ }^{13}$ basic legal provisions guaranteeing public access to information about legislative activities are an important pre-condition for the development of an open, clear and inclusive policy making process. ${ }^{14}$ This argument underlines the assumption that greater levels of democratization, associated with stronger institutions and established practices, are directly linked to a more participatory governance style. ${ }^{15}$

11 Lutsevych, Orysia. "How to Finish a Revolution: Civil Society and Democracy in Georgia,

Moldova and Ukraine." Chatham House, 2013, 10, accessed December 12, 2020 https://

www.chathamhouse.org/sites/files/chathamhouse/public/Research/Russia\%2oand\%2O

Eurasia/on13bp_lutsevych.pdf.

Bhargva, V. "Engaging Citizens and Civil Society to Promote Good Governance and Development Effectiveness." The Governance Brief, 25, 2015.

13 Marin, J. “Evidence of Citizen Engagement Impact in Promoting Good Governance and Anti-Corruption Efforts." U4 Anti-Corruption Resource Centre. Transparency International/Chr.

Michelsen Institute Bergen, 2016, 2.

14 Bhargva, V. "Strategies for Empowering Communities to Demand Good Governance and Seek Increased Effectiveness of Public Service." Partnership for Transparency Fund Working Papers Series No. 4, 2012, 15 .

15 Tătar, M. Importing Democracy from Abroad: International Assistance for Civil Society in Romania. Marius Ioan Tatar, 2006, 21. 
In practice, this indicator refers to the standard of transparency of state activities relating to the provision to the public of timely information about policies, amendments and legislative plans in order to allow for appropriate response on the part of civil society actors. This can manifest itself in the availability of well-established and predictable legislative procedures, information about which is publicly available and reliable, as well as in the degree of transparency of the policy making agenda more generally.

\section{Nature of the legal framework for engagement}

Departing from arguments about the role of democratic political systems in facilitating wider CSO involvement, it can plausibly be assumed that broader, more sophisticated and comprehensive legal framework for engagement with non-state actors is likely to be present in more open political systems. Extensive legal guarantees for civic participation could be a good indication of the state's commitment to incorporating CSOs in the public policy process. Therefore, it is important to look at the existing legislation mandating mechanisms for public inclusion in decision making with special attention being paid to the asymmetrical power relations underlying those mechanisms. In addition, in order to control for the issue of irrelevance of consultations to the actual policy process, which has been identified as a common obstacle to the genuine participation of CSO representatives, ${ }^{16}$ the model also considers whether the law provides for public governance mechanisms which are binding or mandatory in the framework of public policy making or are in other ways meaningfully incorporated into the substantive decision making process.

\section{Degree of institutionalization of dialogue}

This indicator is crucial to the analysis and focuses on the more practical dimensions of state-CSO interaction and cooperation. It seeks to explore the practice of policy dialogue beyond the existing legal framework. This is key as it is recognized that legislation, while indicative of a state's formal commitment to dialogue, rarely represents an exhaustive or accurate picture of the de facto practice of policy making. In fact, the degree of institutionalization of dialogue is particularly relevant to the study of hybrid regimes, where tokenistic as opposed to genuine engagement as well as a more general trend towards prevalence of informal practices over formally established procedures are wellrecognized. ${ }^{17}$

16 Bozzini, E. and S. Fella. "The Role of Civil Society in Immigration Policy Making in Italy: Changing Patterns of Conflictual Cooperation." Policy \& Politics 36, no. 2 (April 1, 2008): 245-59, 254. Fioramonti, L. and F. Heinrich. "How Civil Society Influences Policy: A Comparative Analysis of the CIVICUS Civil Society Index in Post-Communist Europe." Civicus World Alliance for Citizen Participation, 2007, 29. 


\section{Table 1}

CLARITY \& TRANSPAR-

ENCY OF DECISION-

MAKING

Lack of trasparency, unpredictable, arbitrary policy making

TOLERATION Basic transparency guarantees

No clarity about agenda content and details

STATE-

Relative transparency

CONTROLLED through process could be ENGAGEMENT unpredictable at times

LIMITED

DIALOGUE

\section{Clear and predictable}

policy-making process and

policy agenda

LEGAL FRAMEWORK FOR

ENGAGEMENT

No formal or informal mechanism for dialogue exists

Very limited legal provisions for state-CSO communication (sporadic and outside of official policy-making)

Limited although present legal framework for dialogue (non-binding and non-mandatory)

Key legal provisions for dialogue but framework is imperfect

CSO influence on agenda is limited

COLLABORA- Clear and predictable poliTION cy-making process

Commitment to transparency

Some CSO influence on policy agenda

PARTNERSHIP Clear and predictable policy-making process

CSOs contribute to the shaping of political agenda
Exstensive legal framework for engagement throughout the decision-making process Limitation only in highly sensitive fields

Comprehensive legal framework and commitment to dialogue at all states of policy-making Sanctions for non-compliance
DEGREE OF INSTITUTIONALISATION (IN PRACTICE)
No institutionalized forms of dialogue

No CSO influence on policy

Very few (if any) formal platforms for dialogue, which function poorly Very limited real CSO influence on policy

Some degree of formalization exists although in practice effectiveness varies considerably Limited and very selective state responsiveness to input

Reliable and functioning institutionalized channels for consultation exist

Subjective factors determine degree of responsiveness

Relatively high level of institutionalization

Formal mechanisms are reliable Considerable degree of responsiveness in most policy fields

High degree of institutionalization Formal mechanisms are reliable and predictable State authorities are highly responsive to CSO input 
This indicator has two distinct aspects - the de facto respect for the existing legal provisions for CSO participation and consultation as well as the degree of institutionalization of state-CSO dialogue more generally. In this context, the notion of institutionalization is understood as the presence of formal and sustainablestructures and regulations, which guarantee consistent and reliable channels for inclusion regardless of contextual and other subjective factors such as leadership preferences, political will and informal relationships.

Departing from the importance of those three indicators for the establishment of sound participatory governance practices, a model consisting of six ideal-type categories describing state-CSO relations and the degree of state openness to CSO input can be distinguished. Each of these relationship types can be briefly summarized as follows in Table 1.

\section{Repression}

Repression represents the most limited form of political openness to CSO advice and participation. This relationship is likely to be present in environments highly hostile to civil society in general where dialogue might be altogether absent and CSOs might even be facing repression or prosecution. In these conditions, political process is largely closed to the public, lacks even basic principles of transparency and policy decisions are arbitrary and largely dependent on elite preferences. There are no meaningful institutionalized forms of engagement while informal channels of communication, even if existent, are severely limited. CSOs have virtually no influence on policy making.

\section{Toleration}

Toleration is a milder form of state-CSO relations which, however, remains largely closed to meaningful civic impact. While there is basic understanding of the decision-making process and basic information about political agenda might be available, it is normally limited and details about legal content or planned legislative activities are not widely circulated prior to their announcement. Some though very limited legal commitment to state-CSO communication and consultation might exist but framework provides for mostly sporadic and non-binding forms of dialogue with little or no direct relevance to the formal decision-making process. Civic input is often limited to voluntary opinion-sharing in the form of statements or open letters whose main aim is to increase the visibility of public opinion and not to directly influence policy content. Any dialogue that might exist is largely a result of informal relations and not a clear institutionalized commitment. CSOs exercise only minimal policy influence.

\section{State-controlled engagement}

This relationship type is underlined by the clear distinction between engagement, which is seen as one-sided transaction of information largely dominated by the state, and 
dialogue, which is likely to emerge in more advanced stages of state-CSO cooperation and implies an active two-way exchange with the willing participation of both parties.

In this category, decision making is relatively clear and predictable and civil society is aware of the key issues on the policy making agenda, which is, however, largely a result of informal channels of communications and not of high standards of governmental transparency. Some limited legal provisions for CSO engagement exist although they tend to be non-binding and ad hoc and their use is often subject to the discretion of public authorities. Legal framework might foresee forms of civic inclusion, but these are limited to information-sharing implying a one-way flow of information from public authorities to CSOs. Non-compliance with legal provisions for participation is not uncommon and is largely not sanctioned. Some although very low degree of institutionalization of dialogue is present but formal mechanisms often function poorly. Responsiveness to CSO input is limited and tends to be highly selective.

\section{Limited dialogue}

Limited dialogue is the first relationship type in which meaningful receptiveness to CSO input and participation can be observed. Such contexts are characterized by high levels of institutional transparency. Decision making process is clear and predictable, civil society has a thorough understanding of the policy making agenda and access to information which allows it to effectively monitor governmental activity. Civil society actors, however, are limited in their ability to actively shape policy agenda. There is a limited institutional framework for dialogue which guarantees basic principles of civic participation but those are largely non-binding and are not part of the official decision-making cycle. Some key legal provisions are missing. Some reliable channels of formal dialogue are present although informal mechanisms and personal connections are still central in determining their utility and the degree of responsiveness. Although selectivity is common in the state's dialogue with CSO representative, civil society can be said to exercise a reasonable influence on policy outcomes in certain cases.

\section{Collaboration}

Collaborative relations are characterized by transparent and predictable decision-making procedures and a conscious effort on the part of authorities to publicize detailed information about policy agenda through official channels of communication. Civil society actors might exercise some, although not necessarily direct, influence on the policy agenda. There is a sufficiently extensive institutional and legal framework for engagement guaranteeing civic participation in the political process. Limitations are likely to be present when it comes to particularly sensitive issues and policy areas. Most mechanisms for state-CSO interaction are formalized, sustainable and reliable. CSOs exercise a meaningful influence on policy outcomesin a consistent manner across most policy fields. 


\section{Partnership}

Finally, partnership represents the highest degree of political openness to CSO participation. In the conditions of partnership, the policy making process is clear, predictable and well-established and civil society is not only aware of the policy making agenda but is often actively engaged in shaping it. There is a highly institutionalized and well-established legal framework providing for extensive participation of civil society at all stages of decision making as well as for clear sanctions for those who disregard these provisions. Formal mechanisms of de facto co-decision making are the most common form of interaction across various policy fields. State-CSO dialogue is almost entirely formalized within structures, which have considerable influence on policy outcomes and in which CSO can exercise considerable leverage.

\section{Anti-corruption Policy Making in Ukraine: a Case Study}

\section{Transparency and public access to information}

At the most basic level, transparency and public access to information is guaranteed by Article 15 (prohibiting censorship) and Article 34 (guaranteeing freedom of information) of the Constitution of Ukraine. ${ }^{18}$

In addition, Ukraine boasts a relatively comprehensive framework providing citizens with the right to public information through the Law on Access to Public Information, ${ }^{19}$ whose aim is to provide the basic framework for transparency of state activities. ${ }^{20}$ Adopted in 2011, the law remains one of the few commended legislative developments which took place during the term of President Yanukovych..$^{21}$ It provides for a number of mechanisms and channels for public access to information relevant to the policy making process. This includes access to legal acts, draft legislation, agendas of public meetings and a broad range of policy documents such as progress reports on the implementation of target programs carried out by state authorities nationally and locally. Importantly, citizens requesting information are not required to provide justification for their request and authorities are obliged by law to provide a response within 5 working days. This period can be extended to 20 working days in exceptional cases. Citizens, who fail to receive the data they have requested, can appeal to the authorities or the Ombudsman. Limited exceptions from the law's provisions include

18 Constitution of Ukraine. 1996, accessed December 12, 2020, http://zakon5.rada.gov.ua/laws/ show/254\%D॰\%BA/96-\%D॰\%B2\%D1\%8。.

19 Law of Ukraine. Pro dostup do publichnoyi informatsiyi [On Access to Public Information]. No 2939-17, accessed December 12, 2020, http://zakon4.rada.gov.ua/laws/show/2939-17.

20 Ministry of Information Policy of Ukraine. 2017. The access to public information, accessed December 12, 2020, https://mip.gov.ua/en/content/regulyatorna-politika.html.

21 Kobets, R. and O. Ruda. "Mapping Study: CSO Engagement in Policy Formulation and Monitoring of Policy Implementation." EU Civil Society Dialogue for Progress, 2014, 15. 
information deemed a state secret or otherwise confidential and information and documentation designated exclusively for internal use. The legislation applies to all public institutions including the legislative, executive and judicial branches.

The current access to information legislation is widely accepted as comprehensive and sufficiently broad. ${ }^{22}$ This is exemplified by the good performance of Ukraine in the Global Right to Information Rating, a project whose aim is to evaluate the existing legal framework for public access to information in a range of countries across the world. According to the ranking, the Law on Access to Public Information is awarded 108 points out of a maximum of 15 , placing it ahead of the majority of states in the ranking including a number of EU Member States. ${ }^{23}$ Despite such positive evaluations, however, it should be acknowledged that the de facto implementation of the Right to Information provisions is sometimes flawed and information is not always provided in a timely fashion and in the appropriate form. ${ }^{24}$

In the aftermath of the Euromaidan the legal framework for public access to information was boosted by the amendment of the Law on Access to Public Information in the Form of Open Data. ${ }^{25}$ The new law effectively incorporated the open data principle into the provisions of the Law on Access to Public Information and a number of other relevant pieces of legislation. This means that state authorities covered by the legislation are obliged to provide open access to a large share of their data including detailed information about their policy making activitieseffectively eliminating the need for citizens to officially request information in order to access it. Such information must be made available free of charge on the websites of each institution as well as on a centralized open data online platform (www.data.gov.ua).

The development was seen as a notable step towards improving transparency of state activities in the country. ${ }^{26}$ Despite some challenges in the implementation of the law and the actual utilization of the open data ${ }^{27}$ such hopes appear to have been

Lovitt, J. "Civil Participation in Decision Making in the Eastern Partnership Countries Part One: Laws and Policies." Council of Europe, 2016, 87.

RTI Rating. "Ukraine: Global Right to Information Rating," accessed May 3, 2020, https://www. rti-rating.org/country-data/scoring/.

Kobets and Ruda, Mapping Study, 15 .

Law of Ukraine. Pro vnesennya zmin do deyakyh zakoniv Ukraini shodo dostupu do publichnoi informatsii u formi vidkrytyh danyh [On Amendments to Some Laws of Ukraine on Access to Public Information in the Form of Open Data] № 319-19, accessed December 12, 2020, http:// zakon5.rada.gov.ua/laws/show/319-19.

6 United Nations Development Program. "Newly Adopted Open Data Law Propels Ukraine into the Digital Age." UNDP Ukraine, 2015, accessed December 12, 2020, https://www.ua.undp.org/ content/ukraine/en/home/presscenter/articles/2015/o4/16/newly-adopted-open-data-lawpropels-ukraine-into-the-digital-age.html.

7 Council of Europe. “Ukraine: Handbook on Transparency and Citizen Participation.” Partnership for Good Governance, 2017, accessed December 12, 2020, https://rm.coe.int/ handbook-ukraine-eng/168o78406c. 
justified considering the dramatic improvement of Ukraine's score in the Global Open Data Index, where the country boasts $31^{\text {st }}$ place, well-ahead of a number of European states. $^{28}$

Overall, all CSO activists interviewed expressed sufficient satisfaction with the degree of state transparency and their access to policy-related information including texts of drafts, legislative projects and the authorities' policy making agenda more generally. Despite quoting some exceptional legislative initiatives, which were said to have been characterized by relatively greater secrecy at their initial stages of development such as the controversial draft proposal introducing e-declarations for anti-corruption activist, ${ }^{29}$ none of the interviewees expressed concerns about the general level of clarity when it comes to the policy making process and its content. This position was held even by activists who otherwise sharply criticized the authorities for their lack of responsiveness to their suggestions and opinions expressed in relation to such information. ${ }^{30}$

In addition to general access to information legislation, civil society representatives identified a number of additional mechanisms for obtaining relevant policy information. These included a number of consultative platforms bringing together representatives of the state and civil society, such as the organization of weekly discussions of the plenary policy agenda between representatives of the Parliamentary majority and CSO activists, ${ }^{31}$ regular participation in parliamentary committees working on relevant issues $^{32}$ as well as participation in legislative meetings and hearings, which are open to the public. ${ }^{33}$ Interviewees also gave examples of extensive monitoring initiatives such as the project initiated by the Anti-Corruption Action Centre for daily monitoring of parliamentary activity related to anti-corruption. ${ }^{34}$ The presence and the alleged success of such initiatives as well as extensive investigative journalism utilizing publicly available information ${ }^{35}$ implies considerable access to information about the legislative process underway.

Despite the relatively positive evaluation of the general access to information, however, interviewees acknowledged the gradual closing of some previously useful channels for communication in the period since 2014. Examples included the de facto

28 Global Open Data Index. "Place Overview — Global Open Data Index," accessed December 12, 2020 https://index.okfn.org/place/.

Interview with anonymous representative of civil society organization $\mathrm{N}_{5}$. Interviews with anonymous representatives of civil society organizations $\mathrm{N}_{1}, 2,3,4,9,13$ and 14 .

USAID. "The 2015 CSO Sustainability Index for Central and Eastern Europe and Eurasia."

United States Agency for International Development. Bureau for Europe and Eurasia, 2015, 250, accessed December 12, 2020, https://www.usaid.gov/sites/default/files/documents/1861/ Europe_Eurasia_CSOSIReport_2015_Update8-29-16.pdf. Interviews with anonymous representatives of civil society organizations $\mathrm{N} 2$ and 6. 
liquidation of early post-Euromaidan initiatives such as the informal Council of Anti-Corruption Fighters, initiated by former Chairman of the Verkhovna Rada, Andriy Parubiy, which used to bring together MPs and CSO representatives for discussions of the anti-corruption policy agenda and priorities. ${ }^{36}$ Furthermore, in the course of the interviews it was also suggested that there has been an increasing reluctance amongst some MPs to participate in informal forums for communication exchange with CSO representatives due to concerns that visible association with civil society actors might have negative reputational consequences amongst political elites. ${ }^{37}$ Regardless, a number of interviewees pointed at the importance of informal political networks and connections within key law-making bodies for providing insights into the policy making process and agenda..$^{38}$ Overall, the post-Euromaidan access to information was said to represent a considerable break with tradition when compared to the information available during the term of President Yanukovych. According to one interviewee, it was almost impossible for CSO representatives to even secure a meeting with high-ranking state officials at the time. ${ }^{39}$

\section{Clarity and predictability of the policy making process}

While basic provisions ensuring transparency are an essential pre-condition for facilitating the inclusion of CSOs in the decision-making process, they are not a sufficient guarantee that a dialogue would be established effectively. The quality of the legislative process as manifested in the presence of clear, predictable and effective legislative procedures, which are respected, is also an important aspect of the establishment of a successful state-CSO dialogue. In this respect, Ukraine's performance has been more ambiguous, and issues of clarity and predictability exist within both key law-making branches namely the executive and the legislature.

When it comes to the Parliament, criticism of the quality of the legislative process has been linked to the fact it is seen as "too Soviet," 40 overly chaotic and lacking reliable procedures. ${ }^{41}$ The reason for this is the lack of long-term planning and coordination of legislative activities as well as the common practice of violating formal procedures. This is well-exemplified by the fact that unscheduled legislative initiatives, whose presence on the agenda is "difficult to determine," are a common occurrence as is the lack of "sequence of passing legislation" which often results in unplanned activities being voted

$36 \quad$ Interview with anonymous representative of civil society organization $\mathrm{N} 11$.

37 Interview with anonymous representative of civil society organization $\mathrm{N} 14$.

38 Interviews with anonymous representatives of civil society organizations $\mathrm{N}_{1}, 4,6$ and 11.

39 Interview with anonymous representative of civil society organization $\mathrm{N} 14$.

40 Lovitt, J. "Civil Participation in Decision Making in the Eastern Partnership Countries Part Two: Practice and Implementation." Council of Europe, 2016, 299.

41 Zaslavskyi, O. "Draft Concept Paper on the 'End to End' Legislative Process." Agency for Legislative Initiatives, 2017, 2, accessed December 12, 2020, http://parlament.org.ua/wpcontent/uploads/2017/o7/End-to-end_.pdf. 
on before laws that were submitted much earlier. ${ }^{42}$ Similarly, there is a distinct tendency towards passing laws at the first reading as opposed to the customary second which could limit legislative scrutiny and deliberation. ${ }^{43}$ The perception of the legislative process as unclear was reinforced by one of the experts interviewed who possessed legal expertise. ${ }^{44} \mathrm{He}$ suggested that CSO participation is considerably hindered by the unpredictability of the law making process in which official procedures are often disrespected leading to new initiatives and amendments appearing in Parliament without prior notice. Similarly, another interviewee suggested that the practice of controversial drafts appearing apparently out of nowhere has intensified significantly in the anti-corruption sector in particular. ${ }^{45}$

Furthermore, the presence of overly high thresholds for the passing and adoption of legislation hinders effective legislative activity. ${ }^{46}$ The relevance of this issue to productive state-CSO dialogue and successful CSO advocacy was demonstrated by one of the interviewees, who highlighted the fact that despite fruitful dialogue with MPs, many CSO proposals are not incorporated into laws due to the high requirements for support as well as the common problem of lack of quorum. This was said to have been the case with some initiatives aimed at addressing the controversial introduction of e-declarations for activists. ${ }^{47}$ This means that CSO representatives and even MPs have little control over the legislative process even in cases where productive dialogue and consultations do take place.

The lack of streamlined and predictable procedures in the Rada is further exacerbated by the fact that the executive branch and especially the Presidential Administration has managed to considerably increase its de facto influence on public policy making despite formal constitutional power balance. ${ }^{48}$ The shift has created uncertainty about the real center of policy makingbringing informal channels of influence to the forefront and undermining formal procedure. The consequences of this were exemplified by the comments of one interviewee who suggested the consolidation of presidential power has resulted in greater presidential control over individual MPs and the Parliament as a whole, thus allowing the executive to influence legislative

42 Zaslavskyi, Draft Concept Paper, 5.

43 Zaslavskyi, Draft Concept Paper, 6.

44 Interview with anonymous representative of civil society organization $\mathrm{N}_{3}$.

45 Interview with anonymous representative of civil society organization N 9.

46 European Parliament. "Report and Roadmap on Internal Reform and Capacity-Building for the Vekhovna Rada of Ukraine." European Parliament's Needs Assessment Mission to the Verkhovna Rada of Ukraine led by Pat Cox, 2017, 10.

47 Interview with anonymous representative of civil society organization $\mathrm{N} 10$.

48 Sushko, O. "Reforming Ukraine: Policymaking After the Euromaidan." PonarsEuarasia_Policy

Memos, December 18, 2015, 1, accessed December 12, 2020, http://www.ponarseurasia.org/ memo/reforming-ukraine-policymaking-after-euromaidan; Zaslavskyi, Draft Concept Paper, 3. 
activities and outcomes through informal networks. ${ }^{49}$ This naturally has negative implications for the clarity and predictability of legislative outcomes.

\section{Legal framework for engagement}

\section{Citizens' appeals}

Perhaps the oldest mechanism for civic influence on political processes in Ukraine is the citizens' appeal. According to the Law on Citizens' Appeals, which was adopted in $1996^{50}$ every Ukrainian citizen is given the right to appeal directly to a number of public authorities and institutions. Such appeals can take various forms including recommendations on public policies, expression of opinion on existing or drafted legislation or an appeal against decisions made by the state. Appeals and petitions can be submitted verbally, orally or, following the most recent amendment in 2015, electronically. Upon submission, the authorities have the obligation to respond within two weeks.

Although this form of interaction between the state and society appears to be the most common, the tool is largely seen as ineffective in providing a meaningful mechanism for engagement. ${ }^{51}$ The main reason for this is the lack of strict guidelines or requirements for the format of such appeals which often makes them an unhelpful form of interaction with authorities. In addition, although public institutions have the obligation to provide a formal response, appeals are largely irrelevant to the actual decision-making process since policy makers are not obliged to take them into consideration in the process of policy development or to provide any justification for ignoring them. Overall, given its limitations, the citizens' appeals mechanism provides a weak tool for state-CSO interaction and meaningful policy dialogue.

\section{Public expertise}

The possibility for CSOs to provide public expertise is another mechanism allowing for civic input in governance. The procedure was first introduced in the Ukrainian legal framework in 2008 after the adoption of Decree No. 976 by the Ukrainian Cabinet of Ministers. ${ }^{52}$ In short, public expertise is a mechanism which can be initiated by CSOs interested in cooperating with state authorities on the preparation of policy

49 Interview with anonymous representative of civil society organization $\mathrm{N} 14$.

50 Law of Ukraine. Pro zvernennya gromadyan [On the Appeals of Citizens]. № 393/96-BP, accessed December 12, 2020, http://zakon3.rada.gov.ua/laws/show/393/96-\%Do\%B2\%D1\%8o. Kobets and Ruda, Mapping Study, 38.

$5^{2}$ Law of Ukraine. 2008. Pro zatveerdzhennya Poryadku spriyannya preovedennyu gromads'koi ekspertyzi diyal'nosti organiv vykonavchoi vlady [On Approval of the Procedure for Facilitating the Public Examination of the Activities of the Executive Bodies]. № 976, 2008, accessed December 12, 2020, https://zakon.rada.gov.ua/laws/show/976-20o8-\%Do\%BF. 
documents or the monitoring and evaluation of existing legislation and other aspects of state activity. In the process, a number of "expert proposals" are developed for the consideration of the state body in question. The head of the relevant public body is then obliged to provide a response to the recommendations and elaborate on the further steps which are to be undertaken in order to address these recommendations.

Overall, while in theory this mechanism provides a meaningful channel of communication and facilitates state-civil society interaction it has failed to boost the influence of CSOs on the decision-making process. Admittedly, in the post-Euromaidan period the use of public expertise has become more commonin comparison to the first few years of its introduction when the tool remained unpopular and was rarely utilized. ${ }^{33}$ However, given that the current legislative framework mandates that state bodies respond to expert recommendations but does not include an obligation to take those into consideration, this mechanism is limited in its capacity to boost CSO participation in the policy making process and has remained relatively marginal.

\section{Public consultations}

Public consultations are by far the most notable form of inclusion of CSO representatives in public policy making in Ukraine. The concept of public consultations as a part of the policy process was first introduced in 2010 with Resolution No. 996 of the Ukrainian Cabinet of Ministers "On Guaranteeing the Participation of the Public in Public Policy Formation," ${ }^{54}$ whose aim was to guarantee wider involvement of the public and relevant stakeholders in the process of policy development and implementation. Although the regulation does mandate the preparation and approval of annual plans for public consultations by executive bodies both nationally and locally the existing legal framework has a number of notable limitations. First of all, the regulation does not apply to the Presidential Administration or the Parliament, which automatically limits significantly its utility as a comprehensive mechanism for political dialogue with CSOs. Furthermore, despite the fact that authorities are formally obliged to publish information about the outcomes of public consultations within two weeks of their finalization this provision has often been overlooked and authorities are said to have provided such feedback in no more than $30 \%$ of the cases since $2014 .{ }^{55}$

Furthermore, at present consultations are only mandatory in a very limited set of cases including on all drafts of economic regulations and bills linked to nuclear energy or the environment. ${ }^{56}$ The reason for this is that these cases are governed by additional

Kobets and Ruda, Mapping Study, 37.

Law of Ukraine. Pro zabezpechennya uchasti gromadskosti u formuvanni ta realizatsii derzhavnoi polityky [On Ensuring Public Participation in Formation and Implementation of the State Policy]. № 996, accessed December 12, 2020, http://zakon3.rada.gov.ua/laws/show/996-2010$\% \mathrm{D} \% \mathrm{BF}$. Lovitt, Civil Participation Part Two, 271. Lovitt, Civil Participation Part Two, 267. 
legislation such as the Law "On the Principles of State Regulatory Policy in Economic Activity" which mandates consultations as a compulsory pre-condition for the validity of any regulatory acts. ${ }^{57}$ In the vast majority of cases, however, the state of current legislation means that public consultations have a purely advisory, non-binding and voluntary character and state representatives have no formal obligation to carry them out, to consider proposals given in this framework or to justify their decision not to take them into consideration. ${ }^{58} \mathrm{On}$ a more practical note, there is also no clearly set or transparent procedure for the selection of CSO representatives who take part in such consultations when they are carried out.59

More recently, in the aftermath of the Euromaidan and under Ukraine's commitments in the framework of the Open Government Initiative the practice of public consultations was revitalized and evolved considerably. ${ }^{60}$ This fact was highlighted also by interviewees who praised authorities' commitment to genuine consultation in draft development in the early years after the 2014 Revolution. ${ }^{61}$ Some regularly quoted examples from the anti-corruption field of bills developed with a high degree of consultation and participation by CSOs were the Laws on National Anti-Corruption Bureau of Ukraine (NABU), On the Fight Against Corruption and On Asset Management as well as various amendments to the Criminal Code and the legislation needed for the creation of the National Agency for Corruption Prevention (NACP) ${ }^{62}$ The lack of legal obligation to actually carry out such consultations by most institutions, however, was said to considerably constrain the utility of the general consultation provision.

In view of these deficiencies, a number of attempts have been made throughout Ukraine's modern history to adopt a comprehensive Law on Public Consultations. Drafts bills were developed in 2004 and 2010 but they failed to materialize into viable legislation. ${ }^{63}$ The seemingly increased openness to cooperation notwithstanding, legislative framework providing for political dialogue has continued to lag behind even in the aftermath of the Euromaidan. In 2016 and 2017 an attempt was made for

57 Law of Ukraine. Pro zasadi derzhavnoi regulyarnoi politiki u sferi gospodars'koi diyalnosti

[On the Principles of State Regulatory Policy in Economic Activity]. No 116o-15, 2003, accessed

December 12, 2020, http://zakon5.rada.gov.ua/laws/show/116o-15.

$5^{8}$ Council of Europe. "Strategic Priorities for Promoting Civil Participation in Decision making in Ukraine." Council of Europe, 2014, 3, accessed December 12, 2020, https://rm.coe. int/168oocc3d5.

59 Lovitt, Civil Participation Part One, 95.

6o Council of Europe. "Guidelines for Civil Participation in Political Decision making. Adopted by the Committee of Ministers on 27 September 2017 at the 1295th Meeting of the Ministers' Deputies." Council of Europe, 2017, accessed December 12, 2020, https://rm.coe.int/guidelinesfor-civil-participation-in-political-decision making-en/16807626cf.

61 Interviews with anonymous representatives of civil society organizations $\mathrm{N}_{2}, 4,5$.

62 Interviews with anonymous representatives of civil society organizations N 1, 5, 9.

63 Lovitt, Civil Participation Part Two, 311. 
the development of a new law, which would have made consultations an integral and mandatory part of policy making process in most fields including anti-corruption. ${ }^{64}$ Despite initial positive signs such as extensive cooperation with civil society on the preparation of the draft ${ }^{65}$ and a positive evaluation by the OSCE, ${ }^{66}$ the bill failed to move further after it was submitted to Parliament. The reason for this appeared to be internal political opposition. ${ }^{67} \mathrm{CSO}$ representatives identified the absence of comprehensive Law on Consultations as one of the most substantial problems of the current legislative framework for civic participation in Ukraine. ${ }^{68}$

\section{Public councils}

Public councils represent a particular form of consultation and are the most notable aspect of the current Ukrainian framework for engaging CSO representatives in the decision-making process on national and local level. The public council as an advisory mechanism providing a channel for dialogue between CSO representatives and the state was first introduced in the 1990 os and was subsequently reformed twice in order to tackle a number of weaknesses. Public councils' operations in their current form is based on Resolution No. 996 of the Ukrainian Cabinet of Ministers from $2010^{69}$ which requires all public bodies to establish a permanent consultative body (a public council) staffed with CSO representatives. These organs are elected for a period of two years and are tasked with ensuring that the relevant body considers public input in its decision-making process.

The presence of legislative basis for the creation of such permanent advisory bodies is admittedly a notable sign of official commitment to dialogue and participatory policy making. However, the recommendatory character of the opinions of public councils has historically limited their impact on policy as in times of deficient political will their proposals have simply been ignored by state representatives behind the façade of

64 Ash et al., The Stuggle for Ukraine, 68.

65 Open Government Partnership. "Interim Report On Implementation of the Action Plan for Introduction of Open Government Partnership Initiative in 2016-2018." Open Government Partnership, 2018, 29, accessed December 12, 2020, https://www.opengovpartnership.org/ documents/ukraine-mid-term-self-assessment-report-2016-2018.

66 OECD. "Anti-Corruption Reforms in Ukraine. Fourth Round of Monitoring of the Istanbul Anti-Corruption Action Plan." OECD Anti-Corruption Network for Eastern Europe and Central Asia, 2017, accessed December 12, 2020, http://www.oecd.org/corruption/acn/ACN-Ukraine-Round-4-Monitoring-Report-ENG.pdf.

67 Ash et al, The Struggle for Ukraine, 68.

68 Interview with anonymous representative of civil society organization $\mathrm{N}_{5}$.

69 Law of Ukraine. Pro zabezpechennya uchasti gromadskosti u formuvanni ta realizatsii derzhavnoi polityky [On Ensuring Public Participation in Formation and Implementation of the State Policy]. No 996, accessed December 12, 2020, http://zakon3.rada.gov.ua/laws/show/996-2O10\%D॰\%BF. 
public engagement. ${ }^{70}$ Furthermore, the lack of integration of council opinions in the wider policy making process has often allowed for their marginalization by unwilling political actors. These deficiencies in the legislative framework as well as the low cost of non-compliance and sabotage have meant that despite the long history of public consultation in this form, councils have had questionable success in facilitating inclusion of civil society in public governance. A good illustration of the imperfect framework for their creation and operation is their successful marginalization in the pre-2014 period more generally and their complete irrelevance during the term of President Yanukovych. Given the lack of any legal procedure for staffing the councils, the Ministry of Foreign Affairs, for example, incorporated a number of religious organizations but no representatives from think tanks with specialization in foreign policy or other relevant organizations. ${ }^{71}$

\section{Degree of institutionalization of dialogue-legal framework in practice}

As demonstrated, Ukraine's legislative framework for CSO engagement, while having some limitations, provides for at least some notable forms of institutionalized dialogue, namely pubic consultations and public councils. While the design limitations of some more minor legislative mechanisms such as the appeals system and the public expertise procedure have largely deemed them marginal as institutionalized forms of state-CSO dialogue, in theory provisions on consultation through public councils appear to represent a meaningful commitment to formalizing CSO participation in public policy making.

In practice, however, these councils have remained a considerable source of controversy throughout their existence. Their actual effectiveness has often been questioned by experts who have seen them as "Potemkin village" organs, ${ }^{72}$ a "tick-thebox mechanism"73 and a "theater of absurd." 74 The reason for this has been the wellrecognized tendency of the authorities to marginalize such bodies and undermine their real effectiveness and impact through a number of disruptive strategies including the exclusion of relevant but critical CSOs from these structures or even their staffing with

70 Ghosh, M. "In Search of Sustainability: Civil Society in Ukraine." Friedrich Ebert Stiftung, 2014, accessed December 12, 2020, http://library.fes.de/pdf-files/id-moe/10862.pdf. Kharkiv Human Rights Protection Group. "Civic Anger over Hijacked Public Councils," 2013, accessed December 12, 2020, http://khpg.org/en/index.php?id=1361579838. Smagliy, K. “Kennan Cable No. 25: A Wake-up Call for Ukraine’s Civil Society”. Wilson Center, Washington, DC, accessed December 12, 2020, https://www.wilsoncenter.org/publication/ kennan-cable-no25-wake-call-for-ukraines-civilsociety. 
representatives from politically controlled organizations created in order to mimic dialogue. ${ }^{75}$

Considering the poor performance of public councils as a tool for CSO engagement until 2014, the revitalization of these bodies became a top priority of the post-Euromaidan government and civil society. Councils were largely re-staffed and restructured in order to turn them into an effective platform for dialogue. Despite this, however, the majority of the activists who were interviewed remained skeptical about the degree to which public councils provide a reliable and sustainable form of dialogue. ${ }^{76}$ According to them, many councils remain tokenistic and irrelevant as their effectiveness varies considerably based on a number of subjective factors such as political will within the institution in question or leadership preferences. ${ }^{77}$ The most commonly cited illustration of this was the presence of highly efficient councils such as those attached to NABU ${ }^{78}$ or the Asset Recovery and Management Agency, ${ }^{79}$ which succeed in exercising significant real influence in the decision making process, on one hand, and the marginalization of similar structures in less "open" institutions such as the NACP, 80 the National Security Service or the General Prosecutor's Office, on the other. ${ }^{81}$

Notably, most interviewees tended to point at a general trend towards declining willingness for cooperation with councils and with CSOs as a whole since 2016, which was said to be in contrast with relatively higher responsiveness to input in the early days after the Revolution. ${ }^{82}$ In line with opinions about the "illiberal turn" of the later years of the term of President Poroshenko, ${ }^{83}$ the authorities and especially the Presidential Administration were said to have increasingly adopted an overly formalistic approach in handling council recommendations and opinions provided in the course of consultations. As a consequence, certain procedures and mechanisms for participation were said to have considerably declined in effectiveness and to have stopped providing a reliable channel for communication with authorities. ${ }^{84} \mathrm{~A}$ telling example of the declining responsiveness to input provided through official channels for consultation is the fact that while in 2014 and 2015 CSO input was often directly integrated into the

75 Ghosh, In Search of Sustainability, 3.

76 Interviews with anonymous representatives of civil society organizations $\mathrm{N}_{2}, 4,5,6,7,8,11,12$.

77 Interviews with anonymous representatives of civil society organizations $\mathrm{N} 2,4,9$.

78 Interviews with anonymous representatives of civil society organizations $\mathrm{N} \mathrm{2,} \mathrm{4,} 5$.

79 Interview with anonymous representative of civil society organization $\mathrm{N}_{5}$.

$80 \quad$ Interviews with anonymous representatives of civil society organizations $\mathrm{N}_{5}, 7$.

$81 \quad$ Interview with anonymous representative of civil society organization $\mathrm{N}_{4}$.

82 Interviews with anonymous representatives of civil society organizations N 1, 2, 5, 6, 8, 11, 13, 14.

83 Umland, Andreas. "Kyiv's Leadership Is on Its Way to Reinvent Ukraine’s Patronalistic Regime." Open Democracy Online, 2017, accessed December 12, 2020, https://www.opendemocracy.net/ od-russia/andreas-umland/kyiv-s-leadership-is-on-its-way-to-reinvent-ukraine-s-patronalistic-regime.

84 Interviews with anonymous representatives of civil society organizations N 1, 6. 
new laws On NABU, On Corruption Prevention, On Asset Management and a number of other pieces of legislation related to the creation of NACP, more recently, the same mechanisms have proved much less helpful in ensuring civic inclusion in policy making. As pointed out by one of the interviewees, the draft law On the Anti-Corruption Court prepared by CSO experts was largely ignored although it was developed using a similar consultative approach as earlier. ${ }^{85}$

In this context, a trend towards selectiveness and significant fluctuation in the effectiveness of consultations was also said by interviewees to have become prominent. ${ }^{86}$ This means that while in certain institutions such as the Ministry of Health, the Ministry of Education or the Asset Recovery and Management Agency, institutionalized consultative channels continued to provide a reliable basis for dialogue with policy makers, in others such as the Ministry of Internal Affairs or the Presidential Administration, those same channels became largely devoid of purpose. ${ }^{87}$ What is more, even within the same institutions response to CSO input was said to vary considerably depending on the type of issue at hand or, more often, on the type of recommendation issues by civil society experts. ${ }^{88} \mathrm{~A}$ good illustration of this was offered by one of the interviewees who recalledhis participation in a consultation initiated by the Presidential Administration prior to the creation of the National Office of Financial Security. According to the interviewee, although the platform appeared to have started as a genuine attempt to include CSOs in policy making, it was quickly terminated after CSOs expressed strong criticism towards the Administration's plans. ${ }^{89}$

\section{Additional institutional developments}

In addition to the mechanisms outlined in Ukraine's legislation, a number of formal platforms for engagement were set up in the aftermath of the Euromaidan to respond to the demand for greater public participation in the reform process. These have included the establishment of commissions staffed by civil society representatives and tasked with aiding the process of staff selection for a number of institutions, including the new anti-corruption bodies NABU and NACP as well as the judiciary. ${ }^{90}$ Similarly, shortly after the Euromaidan the National Reform Council was set up to serve as a "policy dialogue platform" 91 bringing together CSO experts and government representatives including the President, the Prime Minister, Ministers and chairs of parliamentary committees. The Civil Society Coordination Council and the Reform Support Centre were also set up and tasked with assisting the government in the drafting and implementation of reform

85 Interview with anonymous representative of civil society organization $\mathrm{N} 1$.

86 Interviews with anonymous representatives of civil society organizations $\mathrm{N}_{1}, 5,6,8,11$.

87 Interviews with anonymous representatives of civil society organizations $\mathrm{N}_{5}, 7,9,14$.

88 Interview with anonymous representative of civil society organization $\mathrm{N} 7$.

89 Interview with anonymous representative of civil society organization $\mathrm{N} 1$.

90 Ash et al, The Struggle for Ukraine, 64.

91 Sushko, Reformming Ukraine, 3. 
legislation. Furthermore, regular CSO participation became a common practice in most parliamentary committees and in a number of lower-profile platforms such the Council of Anti-Corruption Fighters in the Parliament. ${ }^{22}$ Regular consultative forums bringing CSO representatives and lawmakers together were set up. These initial institutional developments were acknowledged and praised by interviewees who suggested that 2014 saw real commitment to inclusion of CSOs in policy making for the first time in Ukraine's history. ${ }^{93}$

The establishment of a multitude of formal mechanisms for civic participation certainly points at a considerable commitment to providing a consistent and reliable institutional framework for engaging civil society in policy making. A look at the de facto operation of such formal channels of communication, however, raises questions about the degree to which they can be regarded as reliable indicators of sustainably increased state openness to CSO input. Not only were they said by interviewees to have been of varying effectiveness but many of these apparently institutionalized forums were said to have become increasingly ineffective in practice. Selection committees within the judiciary as well as the NACP became subject to growing political pressure and failed to ensure public control over the selection process in the long run ${ }^{94}$

In addition, the National Reform Council which was praised for its activity until $2015^{95}$ saw the gradual replacement of CSO representatives with politically controlled figures loyal to President Poroshenko such as Iryna Lutsenko, the wife of the controversial Prosecutor General Yuriy Lutsenko. ${ }^{96}$ Similarly, one of the interviewees recalled his experience within the National Council for Anti-Corruption Policypointing out that earlier enthusiasm and productive communication with CSOs gradually faded during the course of existence of the body and meetings became rarer while CSO recommendations became increasingly overlooked. ${ }^{97}$ The Civil Society Coordination Council become subject to great criticism after it failed to respond to a number of assaults on civil society in Ukraine such as the highly controversial legislative plans to introduce mandatory e-declarations for anti-corruption activists. Its apparent disengagement from the decision-making process was seen by some as proof of its political dependence and weakening commitment to promoting participatory governance. ${ }^{98}$

Interviewees also highlighted an increasingly difficult although ongoing interaction with Parliament with the most common example cited being the deteriorating VOLUNTAS: International Journal of Voluntary and Nonprofit Organizations 28, no. 1 (February 1, 2017): 420-49.

93 Interviews with anonymous representatives of civil society organizations $\mathrm{N}_{5}, 8$.

94 Interviews with anonymous representatives of civil society organizations $\mathrm{N}_{3}, 12$.

95 Sushko, Reformming Ukraine, 3.

96 Smagliy, A Wake-up Call for Ukraine's Civil Society.

97 Interview with anonymous representative of civil society organization $\mathrm{N} 11$.

98 Smagliy, A Wake-up Call for Ukraine's Civil Society. 
relationship with the anti-corruption committee within the legislature, a previously productive platform. ${ }^{99}$ The break in relations which was widely perceived to be a result of the replacement of the previous sympathetic chair of the Committee represents a particularly strong manifestation of the central importance of leadership preferences as opposed to institutionalized practices in ensuring meaningful CSO participation in the policy process. ${ }^{100}$ Despite the apparent continuation of civic participation in committee meetings the responsiveness to CSO input was said to have dramatically declined in practice. ${ }^{101}$

The manifest decline in the effectiveness of apparently formalized mechanisms for participatory governance was said to have resulted in, on one hand, the rise of outsider tactics such as protests and litigation which challenge state policy decisions and stand in contrast to participatory governance. ${ }^{102}$ On the other hand, the deterioration of formal cooperation was said to have contributed to the revitalization of informal channels of communication and their establishment as a primary tool for productive cooperation with the authorities in many institutions where genuine political will is lacking. ${ }^{103}$ Although some CSO representatives suggested that their informal communication with state representatives is also becoming increasingly difficult, ${ }^{104}$ the prevailing opinion was that such non-institutionalized channels remain the sole reliable mechanism for influencing public policy in a meaningful way. ${ }^{105} \mathrm{~A}$ good example is the relatively productive relationship established between CSOs and the Anti-Monopoly Committee which was said to be based on the good interpersonal relations between state officials in the institution and CSO representatives which in turn facilitated communication and institutional openness to civic input. ${ }^{106}$

In addition to ensuring responsiveness, reform champions and informal connections were said to have become increasingly important in securing access to relevant decision-makers. This is well-illustrated by the practice of private consultation with CSO experts which was said to have become a common initiative of the Ministry of Health due to the presence of good interpersonal relations between officials and CSO experts in the field. ${ }^{107}$ Similarly, in Parliament informal links with reform-minded MPs were said to be crucial for advancing certain policies in an atmosphere of growing marginalization of CSO representatives in formal discussion forums such as committee hearings. ${ }^{108}$ The fact that such informal dialogue often fails to translate into tangible

Interviews with anonymous representatives of civil society organizations $\mathrm{N} 2,6,7,8$.

100 Interviews with anonymous representatives of civil society organizations $\mathrm{N}_{7}, 8$.

102 Interview with anonymous representative of civil society organization $\mathrm{N} 2$.

103 Interviews with anonymous representatives of civil society organizations $\mathrm{N}_{1}, 2,4,7$.

104 Interview with anonymous representative of civil society organization N 2.

105 Interviews with anonymous representatives of civil society organizations $\mathrm{N}_{1}, 2,4,6$.

106 Interview with anonymous representative of civil society organization $\mathrm{N} 4$.

107 Interview with anonymous representative of civil society organization $\mathrm{N} 14$.

108 Interview with anonymous representative of civil society organization $\mathrm{N} 2$. 
impact on policy decisions due to strong party discipline, ${ }^{109}$ however, points at the vulnerability of such informal channels for civic participation as a basis for inclusive governance.

\section{Findings and Conclusions}

The purpose of this study was to determine whether the public policy making process in Ukraine has become more open to the inclusion and sustained participation of civil society representatives in the aftermath of the Euromaidan in 2014. In order to answer the research question, the Ukrainian legislative framework for institutional transparency and civic engagement as well as the practical dimensions of state-CSO cooperation were examined in detail. The analysis pointed at a number of notable trends.

When considering the conceptual framework presented earlier, post-2014 Ukraine represents a peculiar case study. On one hand, the decision-making process boosts a considerable degree of transparency and some meaningful, although limited, degree of clarity and predictability allowing for nearly unobstructed public access to information, which is expected in highly open political systems. Access to information relevant to the legislative process is guaranteed by law as well as through the presence of intense informal communication and information exchange between relevant political actors and CSO representatives. There is a clear trend towards improved transparency and access to information since 2014, which was confirmed by the testimonies of activists.

Similarly, the country's legal framework for engagement of civil society actors while missing key elements such as a Law on Public Consultations or provisions for mandatory and binding civic input, represents a relatively comprehensive attempt at ensuring that civil society representatives and the public at large are included in the deliberative process even if the use of many of the existing mechanisms is left to the discretion of the authorities.

As a result, according to these two indicators, Ukraine's degree of openness places the country in the higherend of the spectrum of state openness and likely in the Limited Dialogue category.

The exploration of the policy dialogue in practice through the prism of activists' experience, however, paints a more nuanced picture. Although in the initial stages after the Euromaidan there appears to have been a clear push towards the introduction of more formal channels for state-CSO dialogue and the incorporation of CSO representatives in the institutionalized deliberative process, later developments suggest that institutionalization in the sense of firmly embedding the spirit of participatory governance in public policy making has not taken place. Interestingly, the Ukrainian experience also suggests that low levels of institutionalization do not necessarily mean more limited civil society engagement. This is well-demonstrated by the fact that in the first two years after the Euromaidan the low degree of institutionalization appears to have contributed to a much more intensive state-CSO interaction and civil

109 Interview with anonymous representative of civil society organization $\mathrm{N} 4$. 
society inclusion than the one expected based on the formal framework at the time. More recently, however, the varying performance of some formal mechanisms and the gradual undermining and marginalization of others suggest that they have failed to establish themselves as reliable enough as to represent a solid basis for sustained CSO inclusion. Instead, dialogue and state responsiveness remain largely dependent on informal channels of communication, interpersonal connections and the presence of favorable contextual factors such as sympathetic leadership.

The increasingly negative experience of CSO representatives in their interaction with state officials and their participation in the policy process as well as the ongoing marginalization of formal channels for dialogue suggest thatthe de facto openness of the political system is considerably lagging behind expectations. The apparent lack of sustainability of policy dialogue points at a level of openness much lower than this indicated by the state's performance according to the two other indicators. Such discrepancies make the overall qualification of state-CSO relations according to the model problematic. The task of conclusively determining the position of the Ukrainian political system as whole on the spectrum of state-CSO relations is further complicated by the emerging vast differences in civic participation across various state authorities and organs as well as across specific policies.

Overall, as pointed out earlier, the model is useful in illustrating the fluctuation in the intensity of civic participation and in identifying general trends of change between different periods in Ukraine's history. Its direct application to empirical realities, however, is naturally imperfect and of only limited utility.

Undoubtedly, the political process has become considerably more open to dialogue and civic participation since 2014. The increased institutional openness and state receptiveness to $\mathrm{CSO}$ recommendations is demonstrated by both the testimonies of anti-corruption activists directly involved in advocacy activities and by the wider literature and the analysis of the formal arrangements in place. The stark contrast is especially clear when comparisons are drawn with the authoritarian approaches used by the regime established by President Yanukovych. Later examples of backsliding and increasing marginalization of CSO representatives by a number of state bodies, however, suggest that it is too early to speak of an effectively established system of participatory governance. In fact, the formalization of institutional openness and civic engagement appears to pose the most significant challenge to a long-term shift towards governance in Ukraine.

In this context, further research is needed in order for longer-term conclusions and trends to be identified as the situation remains volatile and its future development is difficult to predict. This is especially true in view of the election of President Volodymyr Zelensky, an apparent political outsider, in 2019. Furthermore, while the present study does identify important systemic trends, its exclusive focus on anti-corruption and CSOs operating on the national level make generalizations about the political system at large limited. Further academic research looking at a wider spectrum of policy areas and incorporating local level civil society organizations as well as less structured activism 
is needed for a fully comprehensive understanding of the topic to be developed and for the wider validity of the present conclusions to be determined. Finally, although direct policy advocacy represents a key aspect of civil society's input into the political process civic policy impact is not limited to it. An exploration of other, more indirect ways in which CSOs and the wider public can influence political outcomes would be informative in the wider context of public governance debates in Ukraine.

\section{Bibliography}

Ash, T., J. Gunn, J. Lough, O. Lutsevych, J. Nixey, J. Sherr and K. Wolczuk. "The Struggle for Ukraine. Chatham House Report." Chatham House. London, 2017.

Bellamy, Richard, and Antonino Palumbo, eds. From Government to Governance. The Library of Contemporary Essays in Political Theory and Public Policy. Farnham, Surrey, England; Burlington, VT: Ashgate Pub. Co, 2010.

Bhargva, V. "Engaging Citizens and Civil Society to Promote Good Governance and Development Effectiveness." The Governance Brief, 25, 2015.

Bhargva, V. "Strategies for Empowering Communities to Demand Good Governance and Seek Increased Effectiveness of Public Service." Partnership for Transparency Fund Working Papers Series No. 4, 2012.

Bonnafous-Boucher, M. "From Government to Governance." Ethical Perspectives, no. 4 (2005): $5^{21-34 .}$

Bozzini, E. and S. Fella. "The Role of Civil Society in Immigration Policy Making in Italy: Changing Patterns of Conflictual Cooperation." Policy \& Politics 36, no. 2 (April 1, 2008): 245-59.

Burlyuk, O., N. Shapovalova, and K. Zarembo. "Introduction to the Special Issue Civil Society in Ukraine: Building on Euromaidan Legacy." Kyiv-Mohyla Law and Politics Journal 3 (2017): 1-22.

Constitution of Ukraine. Konstytutsiya Ukrainy. 1996. Accessed December 12, 2020. http://zakon5.rada.gov.ua/laws/show/254\%D॰\%BA/96-\%Do\%B2\%D1\%8o.

Coston, J. "A Model and Typology of Government-NGO Relationships." Nonprofit and Voluntary Sector Quarterly 27 (1998): 358-82.

Council of Europe. "Guidelines for Civil Participation in Political Decision-Making. Adopted by the Committee of Ministers on 27 September 2017 at the 1295th Meeting of the Ministers' Deputies." Council of Europe, 2017. Accessed December 12, 2020. https://rm.coe.int/guidelines-for-civil-participation-in-political-decision-makingen/168o7626cf.

Council of Europe. "Strategic Priorities for Promoting Civil Participation in Decision-Making in Ukraine." Council of Europe, 2014. Accessed December 12, 202O. https:// rm.coe.int $/ 168$ oocc $3 \mathrm{~d}_{5}$.

Council of Europe. "Ukraine: Handbook on Transparency and Citizen Participation.” Partnership for Good Governance, 2017. Accessed December 12, 2020. https:// rm.coe.int/handbook-ukraine-eng/168078406c. 
Džatková, V. "The Role of Civil Society in Public Governance." Rocznik Administracji Publicznej 2 (2016): 373-83.

European External Action Service. "Code of Good Practice for Civil Participation in the Decision-Making Process. Adopted by the Conference of INGOs at Its Meeting on 1st October 2009." EEAS, 2009. Accessed December 12, 2020. https://www.eesc. europa.eu/resources/docs/code-of-good-pratice-for-civil-participation-in-thedecision-making-process-en.pdf.

European External Action Service. "Ukraine_EU Country Roadmap for Engagement with Civil Society 2014-2017." European External Action Service, 2014. Accessed December 12, 2020. https://eeas.europa.eu/headquarters/headquarters-homepage_en/10421/Ukraine\%2o-\%2oEU\%2oCountry\%2oRoadmap\%2ofor\%2o engagement\%2owith\%2oCivil\%2oSociety\%2O2014-2017.

European Parliament. "Report and Roadmap on Internal Reform and Capacity-Building for the Vekhovna Rada of Ukraine." European Parliament's Needs Assessment Mission to the Verkhovna Rada of Ukraine led by Pat Cox, President of the European Parliament 2002-2004, 2017.

Evers, A. "Shift in the Welfare Mix: Introducing a New Approach for the Study of Transformations in Welfare and Social Policy." In Shifts in the Welfare Mix, edited by A. Evers and H. Wintersberger, 7-29. Boulder, CO: Westview Press, 1990.

Falsini, S. and S. Worschech. The Euromaidan's Effect on Civil Society: Why and How Ukrainian Social Capital Increased after the Revolution of Dignity. Soviet and Post-Soviet Politics and Society, Vol. 182. Stuttgart.

Fioramonti, L. and F. Heinrich. "How Civil Society Influences Policy: A Comparative Analysis of the CIVICUS Civil Society Index in Post-Communist Europe." Civicus World Alliance for Citizen Participation, 2007. Accessed December 12, 2020. https://www.civicus.org/view/media/CIVICUS.ODI.Fioramonti.Heinrich.pdf.

Ghaus-Pasha, A. "Role of Civil Society Organisations in Governance." Seoul, Republic of Korea, 2004. Accessed December 12, 2020. http://unpan1.un.org/intradoc/groups/ public/documents/un/unpano19594.pdf.

Ghosh, M. "In Search of Sustainability: Civil Society in Ukraine." Friedrich Ebert Stiftung, 2014. Accessed December 12, 2020. http://library.fes.de/pdf-files/id-moe/10862. pdf.

Giugni, M. and F. Passy. "Contentious politics in complex societies: new social movements between conflict and cooperation." In From Contention to Democracy, edited by Giugni, M., D. McAdam, and C. Tilly, 81-107. Md: Rowman \& Littlefield Publishers, 1998.

Global Open Data Index. "Place Overview—Global Open Data Index." Accessed May 3, 2020. https://index.okfn.org/place/.

Karl, M. "Participatory Policy Reform from a Sustainable Livelihoods Perspective: Review of Concepts and Practical Experiences". LSP Working Paper 3, Participation, Policy and Local Governance Sub-Programme. FAO, Rome, 2002. Accessed April 13, 2020. http://www.fao.org/docrep/oo6/ad688e/ad688eo3.htm. 
Kharkiv Human Rights Protection Group. “Civic Anger over Hijacked Public Councils,” 2013. Accessed December 12, 2020. http://khpg.org/en/index.php?id=1361579838.

Kobets, R. and O. Ruda. "Mapping Study: CSO Engagement in Policy Formulation and Monitoring of Policy Implementation." EU Civil Society Dialogue for Progress, 2014. Accessed December 12, 2020. http://www.csdialogue.eu/sites/default/files/ mapping_ukraine_1-3_o.pdf.

Krasynska, S. and E. Martin. "The Formality of Informal Civil Society: Ukraine's EuroMaidan." VOLUNTAS: International Journal of Voluntary and Nonprofit Organizations 28, no. 1 (February 1, 2017): 420-49.

Law of Ukraine. Pro dostup do publichnoyi informatsiyi [On Access to Public Information]. No 2939-17. Accessed December 12, 2020. http://zakon4.rada.gov. ua/laws/show/2939-17.

Law of Ukraine. Pro vnesennya zmin do deyakih zakoniv Ukraini shodo dostupu do publichnoi informatsii u formi vidkritih danih [On Amendments to Some Laws of Ukraine on Access to Public Information in the Form of Open Data]. № 319-19. Accessed December 12, 2020. http://zakon5.rada.gov.ua/laws/show/319-19.

Law of Ukraine. Pro zabezpechennya uchasti gromadskosti u formuvanni ta realizatsii derzhavnoi polityky [On Ensuring Public Participation in Formation and Implementation of the State Policy]. № 996. Accessed December 12, 2020. http:// zakon3.rada.gov.ua/laws/show/996-2010-\%D॰\%BF.

Law of Ukraine. Pro zasadi derzhavnoi regulyarnoi politiki u sferi gospodars'koi diyalnosti [On the Principles of State Regulatory Policy in Economic Activity]. No 116o-15. Accessed December 12, 2020. http://zakon5.rada.gov.ua/laws/show/116o-15.

Law of Ukraine. Pro zatveerdzhennya Poryadku spriyannya preovedennyu gromadskoi ekspertyzi diyal'nosti organiv vykonavchoi vlady [On Approval of the Procedure for Facilitating the Public Examination of the Activities of the Executive Bodies]. No 976. Accessed December 12, 2020. https://zakon.rada.gov.ua/laws/show/9762008-\%D॰\%BF.

Law of Ukraine. Pro zvernennya gromadyan [On the Appeals of Citizens]. № 393/96BP. Accessed December 12, 202O. http://zakon3.rada.gov.ua/laws/show/393/96$\%$ D。\%B2\%D1\%8。.

Lievens, M. "From Government to Governance. A Symbolic Mutation and Its Repercussions for Democracy." Political Studies, 2015.

Lovitt, J. "Civil Participation in Decision Making in the Eastern Partnership Countries Part One: Laws and Policies.” Council of Europe, 2016.

Lovitt, J. "Civil Participation in Decision Making in the Eastern Partnership Countries Part Two: Practice and Implementation." Council of Europe, 2016.

Marin, J. "Evidence of Citizen Engagement Impact in Promoting Good Governance and Anti-Corruption Efforts." U4 Anti-Corruption Resource Centre. Transparency International/Chr. Michelsen Institute Bergen, 2016.

Ministry of Information Policy of Ukraine. The access to public information. Ministry of Information Policy of Ukraine Official Website. Accessed on May 3, 2020. https:// mip.gov.ua/en/content/regulyatorna-politika.html. 
Open Government Partnership. "Interim Report On Implementation of the Action Plan for Introduction of Open Government Partnership Initiative in 2016-2018." Open Government Partnership, 2018. Accessed December 12, 2020. https:// www.opengovpartnership.org/documents/ukraine-mid-term-self-assessment-report-2016-2018.

Pollard, A. and J. Court. "How Civil Society Organisations Use Evidence to Influence Policy Processes: A Literature Review. Working Paper 249." Overseas Development Institute. 2005. Accessed December 12, 2020. https://www.odi.org/sites/odi.org. uk/files/odi-assets/publications-opinion-files/164.pdf.

Rhodes, R. W. “The New Governance: Governing without Government." Political Studies 44, no. 4 (1996): 652-67.

RTI Rating. "Ukraine: Global Right to Information Rating." Accessed May 3, 2020. https://www.rti-rating.org/country-data/scoring/.

Sereda, V. “'I Am a Man and an Active Citizen... I Did Not Betray My State!'” Revue Detudes Comparatives Est-Ouest no. 2 (2018): 93-130.

Shyrokykh, K. “The Euromaidan's Effect on Civil Society. Why and How Ukrainian Social Capital Increased After the Revolution of Dignity." Europe-Asia Studies 72, no. 2 (2020): 333-34.

Silpakar, S. 2012. "Policy Advocacy Strategies of Civil Society Organizations in Nepal. Policy Discussion Paper-4/2012." Alliance for Social Dialogue, 2012. Accessed December 12, 2020. http://asd.org.np/wp-content/uploads/2015/o3/policy_ advocacy_strategies_of_civil_society_organizations_in_nepalo.pdf.

Singh, R. "Civil Society and Policymaking in India: In Search of Democratic Spaces: A Case Study." Oxfam India. Centre for Democratic and Social Action, 2014.

Smagliy, K. “Kennan Cable No. 25: A Wake-up Call for Ukraine's Civil Society”. Wilson Center, Washington, DC. Accessed December 12, 2020. https://www.wilsoncenter. org/publication/kennan-cable-no25-wake-call-for-ukraines-civilsociety.

Sushko, O. "Reforming Ukraine: Policymaking After the Euromaidan." PonarsEuarasia Policy Memos, December 18, 2015, 1. Accessed December 12, 2020. http://www. ponarseurasia.org/memo/reforming-ukraine-policymaking-after-euromaidan.

Sushko, O. and O. Prystayko. "Nations in Transit 2016-Ukraine." Freedom House, 2016, 7. Accessed December 12, 2020. https://freedomhouse.org/report/nations-transit/2016/ukraine.

Tătar, M. Importing Democracy from Abroad: International Assistance for Civil Society in Romania. Marius Ioan Tatar, 2006.

Umland, A. "Kyiv's Leadership Is on Its Way to Reinvent Ukraine's Patronalistic Regime." Open Democracy Online, 2017. Accessed December 12, 2020. https://www. opendemocracy.net/od-russia/andreas-umland/kyiv-s-leadership-is-on-its-wayto-reinvent-ukraine-s-patronalistic-regime.

United Nations Development Program. "Newly Adopted Open Data Law Propels Ukraine into the Digital Age." UNDP Ukraine, 2015. Accessed May 3, 202O. https:// 
www.ua.undp.org/content/ukraine/en/home/presscenter/articles/2015/o4/16/ newly-adopted-open-data-law-propels-ukraine-into-the-digital-age.html.

USAID. "The 2015 CSO Sustainability Index for Central and Eastern Europe and Eurasia." United States Agency for International Development. Bureau for Europe and Eurasia, 2015, 250. Accessed December 12, 2020. https://www.usaid. gov/sites/default/files/documents/1861/Europe_Eurasia_CSOSIReport_2015_ Update8-29-16.pdf.

Vakulenko, V., N. Grynchuk, and H. Borshch. "Report on Public Administration Reform in Ukraine." Network of Institutes and Schools of Public Administration in Central and Eastern Europe (NISPAcee), 2014.

Zaslavskyi, O. "Draft Concept Paper on the 'End to End' Legislative Process." Agency for Legislative Initiatives, 2017. Accessed December 12, 2020. http://parlament.org.ua/ wp-content/uploads/2017/o7/End-to-end_.pdf.

Denitsa Marchevska holds a BSc in Politics with International Relatons from the University of Bath in the United Kingdom and a MA in Russian and Eurasian Studies from Leiden University in the Netherlands. Her research interests include democratic quality, corruption, reforms and public policy making in hybrid regimes. She is currently working towards pursuing doctoral studies in this area.

Acknowledgments: The fieldwork informing this paper would not have been possible without the funding made available by the Netherlands Association for Scientific Research in the context of the research project Civil Society against Corruption in Ukraine: Political Roles, Advocacy Strategies and Impact, of which this author was a part. I want to express my gratitude to Dr. Max Baderand to Dr. Matthew Frear from Leiden Universityfor their support and insights. 


\title{
Партисипативне Управління в Україні: Кейсове Дослідження Антикорупційної Політики за Період 2014-2018 pp
}

\author{
Деніца Марчевська \\ докторант \\ Ляйденський університет, Нідерланди
}

\begin{abstract}
Анотація
Революція Євромайдану 2013-2014 років, яка стала кульмінацією авторитарного та горезвісно корумпованого режиму президента Віктора Януковича, стала символом тріумфу громадської діяльності в Україні. Незважаючи на те, що ці події були під пристальною увагою багатьох дослідників, питання про те, чи зміг протестний потенціал українських громадських організацій успішно перетворитися у формалізовані й продуктивні форми громадської участі у формуванні публічної політики, залишилося поки не охопленим дослідженнями науковців. Тому, ця стаття ставить за мету дослідити чи стали громадські організації в Україні більш інтегрованими в процес формування публічної політики після Євромайдану, і чи Революція змогла спонукати до більш ціннісного зрушення в напрямку більш відкритого та інклюзивного стилю управління. Базуючись на юридичних текстах, зовнішніх доповідях, та напівструктурованих інтерв'ю з київськими представниками громадських організацій, дослідженням вдалося встановити чіткий тренд до збільшення відкритості в процесі формування публічної політики до внеску громадських організацій у негайне втілення здобутків Революції поряд із недостатньою консолідацією та інституціоналізацією таких механізмів, що робить їх вразливими до преференцій окремих гравців, а також до ширших змін у політичних вподобаннях.
\end{abstract}

Ключові слова: громадянське суспільство, партисипативне управління, антикорупційна діяльність, публічна політика, Україна 